\title{
Structure of Alkali-Swelling Bacterial Cellulose-Brightener Complex
}

\author{
Akira KAI and Ping Xu \\ Department of Industrial Chemistry, Faculty of Technology, Tokyo Metropolitan University, \\ Fukazawa, Setagaya, Tokyo 158, Japan
}

(Received June 19, 1990)

\begin{abstract}
The structure of alkali-swelling samples for cellulose-brightener complexes, which were prepared from the Acetobacter-culture in the presence of a fluorescent brightener, was examined. The X-ray diffraction diagram of $10.4 \%$ alkali-swelling complex of the brightener content of $0.095 \mathrm{~mol}$ (per mol of glucose residue) did not show diffraction patterns of the Na-Cell I, but those of the complex. With the decrease of the brightener content in the complex, the formation of $\mathrm{Na}-\mathrm{Cell} \mathrm{I}$ is facilitated. The complex of the brightener content of $0.059 \mathrm{~mol}$ was not transformed into $\mathrm{Na}-\mathrm{Cell}$ I when treated with aqueous $\mathrm{NaOH}$ solution below $8.2 \mathrm{wt} \%$, but it formed Cell II after regeneration. In the case of alkali concentration of $9.0 \%$, however, Na-Cell I was yielded in this complex. On alkali-treatment above $10.4 \mathrm{wt} \%$, the formation of $\mathrm{Na}-\mathrm{Cell} \mathrm{I}$ is facilitated still more. Even when this complex was treated with an alkaline solution of 4.3 and $5.0 \%$, production of Na-Cell I could not be confirmed althrough Cell II was yielded. It became clear from this examination that $\mathrm{Na}$-Cell $\mathrm{I}$ is not formed during the alkali-swelling process possibly due to the cross-linking of the brightener with the cellulose sheets, although Cell II produces by the regeneration. These facts strongly suggest that in the alkali-swelling process, Cell II is only formed by the change in the conformation of the chains without significant change in the apparent shape of the microfibril. Therefore, the direction of chains in it is the same as that of chains in conventional bacterial cellulose.
\end{abstract}

KEY WORDS Acetobacter xylinum / Extracellular Polysaccharide / Fluorescent Brightener / Cellulose-Brightener Complex / Brightener Content / Cellulose Sheet / Alkali-Swelling Complex / Cross-Linking Effect / Parallel Chain Form /

The cellulose obtained from the Acetobacterculture in the presence of a fluorescent brightener, one of the direct dyes for cellulose, forms a crystalline complex containing the brightener between its (110) planes. ${ }^{1}$ This brightener complex shows singular behavior of mercerization. $^{2-6}$ Although no dependence of the brightener content on the X-ray diffraction diagram of the complex is found, the dependence on the resistance toward alkali of the complex is very large. The resistance of the complex becomes greatest at $0.095 \mathrm{~mol}$ (per mol of glucose residue) of the brightener content, which corresponds to the concentration for the saturation of dyeable sites, and the resistance decreases with the decrease of the content. This fact suggests that, since the brightener becomes insoluble in aqueous alkaline solution of more than a few percent, it may be cross-linked with the cellulose sheets corresponding to the (1Ti) plane, and prevents direct bonding between the sheets. ${ }^{3-6}$

It is generally accepted that cellulose I (Cell I) is composed of parallel chains, ${ }^{7,8}$ whereas Cell II is composed of anti-parallel chains. ${ }^{9,10}$ It is assumed on the basis of these models that in the alkali-swelling process of Cell I, the chains of different directions mutually diffuse and form $\mathrm{Na}-\mathrm{Cell} \mathrm{I}$, and this alkali-cellulose changes into Cell II after washing. ${ }^{11-13}$ Being influenced by the cross-linking of the dye, the structure of the alkali-swelling brightener complex is very interesting in clarifying the formation mechanism of Cell II by alkali- 
treatment of Cell I and its structure. In this paper, the structure of the alkali-swelling complex was examined by $\mathrm{X}$-ray methods.

\section{EXPERIMENTAL}

\section{Material}

Brightener Complex. The complex was prepared after the methods described in the previous papers. ${ }^{1,6} 60 \mathrm{ml}$ of cell suspension (Acetobacter xylinum IFO 13693, ATCC 23769) were added to $140 \mathrm{ml}$ of the complex medium ( $\mathrm{pH} 7$ ) with the brightener of a given concentration (ranging from 0.005 to $0.1 \mathrm{wt} \%$ ), and this was incubated at $28.0^{\circ} \mathrm{C}$ for $24 \mathrm{~h}$.

Alkali-Swelling of Complex. To the incubated medium mentioned above was added dropwise an equal volume of aqueous $\mathrm{NaOH}$ solution twice the given concentration. After stirring homogeneously the alkaline solution, it was held at $20.0^{\circ} \mathrm{C}$ for a given time. Then the alkali-swelling sample was pressed to reduce the total weight to about three times the weight of cellulose. This sample was introduced into a $1.5 \mathrm{~mm}$ diameter glass capillary tube.

Alkali-Treated Sample. The samples were prepared after the methods described in the previous paper. ${ }^{6}$ The alkali-swelling complex was neutralized with aqueous acetic acid solution, washed until sodium acetate-free, and then dried.

The abbreviation of samples prepared is shown in Table I.

\section{$X$-Ray Measurements}

$X$-Ray Profiles. An X-ray diffraction diagram was recorded with a flat-film camera with Ni filtered $\mathrm{Cu} K_{\alpha}$ radiation $(40 \mathrm{kV}, 40 \mathrm{~mA})$ with Rigaku, Rota-Unit RU-3v. Diffraction profiles were obtained from the X-ray photos using a densitometer (Konika, PDH-36). Diffraction profiles of the samples were obtained by subtracting the profile of the capillary from those of the capillaries containing the alkaliswelling samples, as shown in Figure 1.
Table I. Abbreviations of samples used

\begin{tabular}{|c|c|c|c|c|}
\hline \multirow{2}{*}{ Sample } & \multicolumn{4}{|c|}{$\mathrm{wt} \%$ of brightener in the medium } \\
\hline & 0.005 & 0.01 & 0.05 & 0.1 \\
\hline Complex & 0.005 & 0.01 & 0.05 & 0.1 \\
\hline $\begin{array}{l}\text { Alkali-swelling } \\
\text { complex }\end{array}$ & $0.005 \mathrm{~S}$ & $0.01 \mathrm{~S}$ & $0.05 \mathrm{~S}$ & $0.1 \mathrm{~S}$ \\
\hline $\begin{array}{l}\text { Alkali-treated } \\
\text { sample }\end{array}$ & $0.005 \mathrm{ND}$ & $0.01 \mathrm{ND}$ & $0.05 \mathrm{ND}$ & $0.1 \mathrm{ND}$ \\
\hline
\end{tabular}

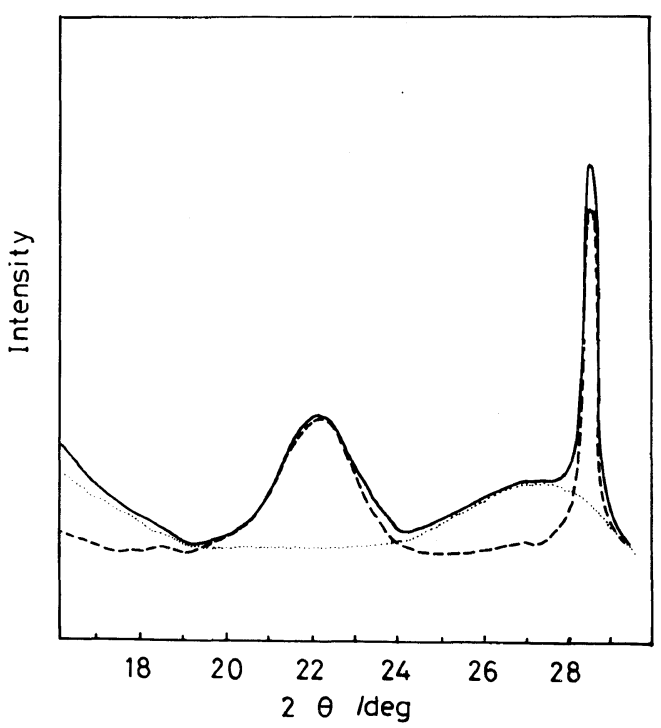

Figure 1. X-Ray profiles of $0.005 \mathrm{~S}$ sample and capillary: — capillary only; ------, alkali-swelling sample (after washing by $0.2 \mathrm{wt} \%$ aqueous $\mathrm{NaOH}$ solution at room temperature, then being pressed to the total weight to about three times of weight of cellulose).

When the diffraction profile of the sample was found to be composed of plural diffractions, the analysis of diffraction curve was performed on the assumption that each profile was Gaussian distribution. $2 \theta$ value of each peak in diffraction profile was exactly determined by using the space of the (111) plane of $\mathrm{Si}$ powder, which was added as standard material to the capillary.

Measurement of Cell II content in the alkali-treated sample: The content was obtained after the methods described in the 
Table II. Brightener contents in the complexes

\begin{tabular}{lllll}
\hline & \multicolumn{4}{c}{ wt\% of brightener in the medium } \\
\cline { 2 - 5 } & 0.005 & 0.01 & 0.05 & 0.1 \\
\hline $\begin{array}{l}\text { Brightener } \\
\text { mol mol }{ }^{-1} \text { of } \\
\text { glucose residue }\end{array}$ & 0.059 & 0.083 & 0.095 & 0.096 \\
\hline
\end{tabular}

previous paper. ${ }^{6}$

\section{Measurement of the Brightener Content in the Complex}

The content was determined after the method described in the previous paper. ${ }^{6}$ The result is shown in Table II.

\section{RESULTS AND DISCUSSION}

The $2 \theta$ value of the diffraction peak of the wet complex which was washed thoroughly with $0.2 \%$ aqueous $\mathrm{NaOH}$ solution equals that $\left(2 \theta=22.3^{\circ 6}\right)$ of the $(020)$ plane of the complex, as shown in Figure 1. This value did not change by the brightener content.

The relation of $2 \theta$ value of the diffraction peak of the $10.4 \%$ alkali-swelling complex and the brightener content is shown in Figure 2. With decrease of brightener content, the $2 \theta$ value approached that of $\mathrm{Na}$-Cell I $\left(20.0 \pm 0.2^{\circ}\right)$. In contrast, the $2 \theta$ value approached that of the (020) plane of the complex $\left(22.3 \pm 0.2^{\circ}\right)$ with increasing brightener content. The $2 \theta$ values of both $0.05 \mathrm{~S}$ and $0.1 \mathrm{~S}$ samples are almost the same as the $2 \theta$ value of the complex. This indicates that $\mathrm{Na}$-Cell I more easily forms from the complex with decreasing brightener content.

When the 0.005 sample which is most easily transformed into $\mathrm{Na}-\mathrm{Cell} \mathrm{I}$ is treated with $6.0 \%$ alkaline solution, the yield of Cell II is $16 \%$ as shown in Table III. In the cases of 7.0 and $8.2 \%$ alkaline solutions, the yields of Cell II are 36 and $44 \%$, respectively. However, in the case of the alkali-treatment with the solution less that $8.2 \%$ even for $24 \mathrm{~h}$, the $\mathrm{X}$-ray

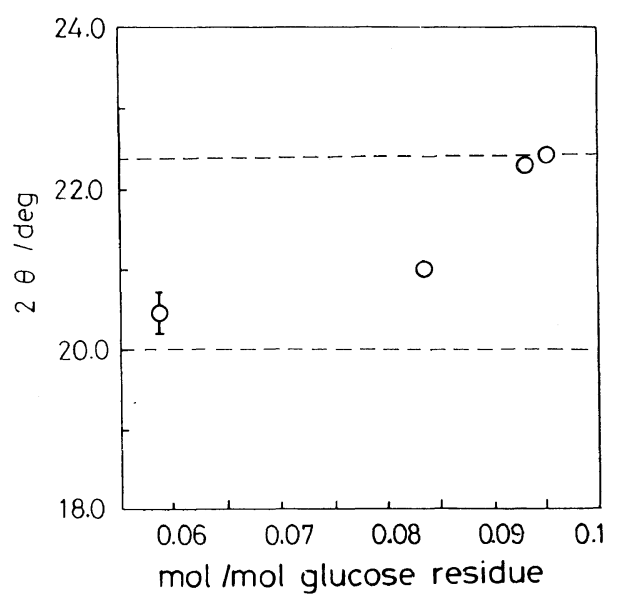

Figure 2. Relation of $2 \theta$ values of diffraction peaks of $10.4 \%$ alkali-swelling samples and brightener content: Upper dotted line, $2 \theta$ value $\left(22.3 \pm 0.2^{\circ}\right)$ of the diffraction peak of the complex; down dotted line, $2 \theta$ value $\left(20.0 \pm 0.2^{\circ}\right)$ of the diffraction peak of $\mathrm{Na}$-Cell $\mathbf{I}$.

Table III. Cell II contents in alkali-treated complexes ${ }^{a}$

\begin{tabular}{lccccccc}
\hline \multirow{2}{*}{ Sample } & \multicolumn{7}{c}{ wt \% of $\mathrm{NaOH}$} \\
\cline { 2 - 7 } & 5.0 & 6.0 & 7.0 & 8.2 & 9.0 & 10.4 \\
\hline $0.005 \mathrm{ND}$ & 0 & 16 & 36 & 44 & 60 & 81 \\
$0.01 \mathrm{ND}$ & - & - & - & - & - & 61 \\
$0.05 \mathrm{ND}$ & - & - & - & - & - & 30 \\
$0.1 \mathrm{ND}$ & - & - & - & - & - & 30 \\
\hline
\end{tabular}

a Treatment time, $1 \mathrm{~h}$.

diffraction profiles for the $0.005 \mathrm{~S}$ sample are almost the same as the profile of the complex, and the formation of $\mathrm{Na}-\mathrm{Cell} \mathrm{I}$ connot be confirmed, as shown in Figures 3 and 4. Although $0.05 \mathrm{~S}$ and $0.1 \mathrm{~S}$ samples treated with $10.4 \%$ alkali solution similarly show the same $\mathrm{X}$-ray diffraction profile as that of the complex, ${ }^{5}$ Cell II of $30 \%$ is included in samples $0.05 \mathrm{ND}$ and $0.1 \mathrm{ND}$, as shown in Table III. These results suggest that, in the case of alkali-treatment of the brightener complex, there is no necessity for the formation of $\mathrm{Na}-\mathrm{Cell} \mathrm{I}$ to form Cell II.

Production of $\mathrm{Na}-\mathrm{Cell} \mathrm{I}$ in the $9.0 \%$ alkali-treated $0.005 \mathrm{~S}$ sample was found, as 


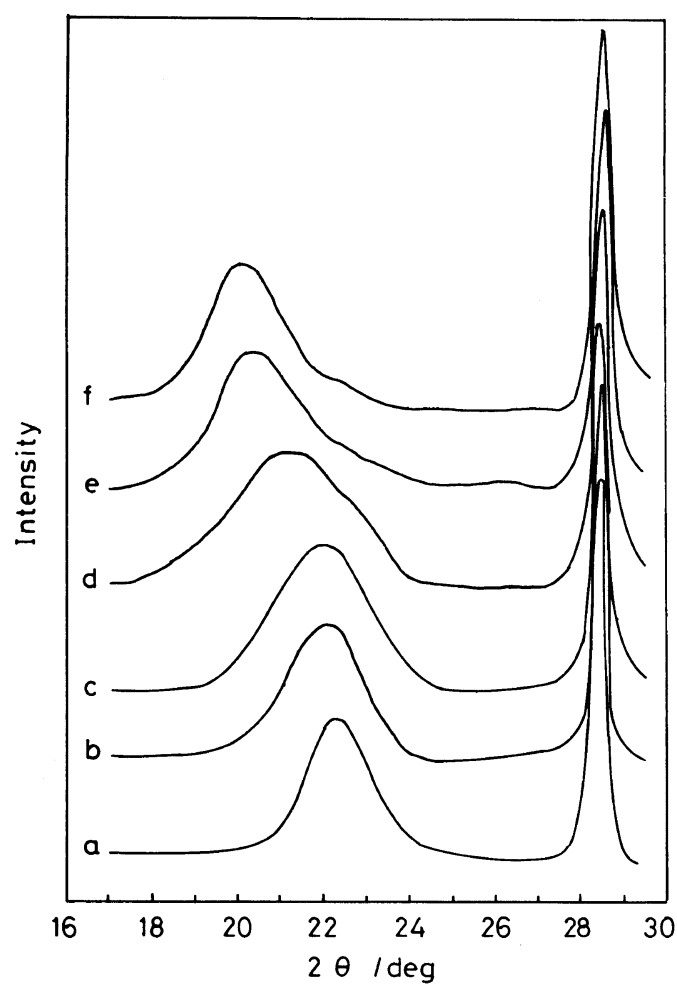

Figure 3. X-Ray profiles of $0.005 \mathrm{~S}$ samples treated with aqueous $\mathrm{NaOH}$ solution of various concentrations. Treatment condition: $20.0^{\circ} \mathrm{C}, 24 \mathrm{~h}, \mathrm{NaOH}$ concentration (wt \%); a, 0.2; b, 5.0; c, 8.2; d, 9.0; e, 10.4; f, 18.0.

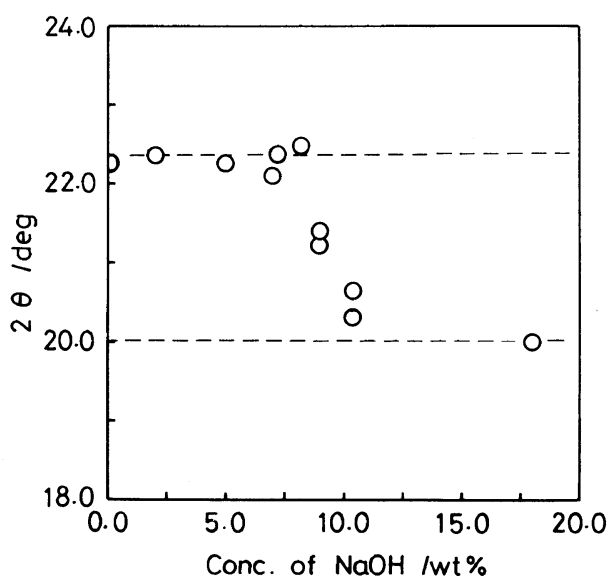

Figure 4. Relation of $2 \theta$ values of diffraction peaks for $0.005 \mathrm{~S}$ sample and $\mathrm{NaOH}$ concentrations: Upper dotted line; $2 \theta$ value $\left(22.3 \pm 0.2^{\circ}\right)$ of the diffraction peak of the complex; down dotted line, $2 \theta$ value $\left(20.0 \pm 0.2^{\circ}\right)$ of the diffraction peak of $\mathrm{Na}-\mathrm{Cell} \mathrm{I}$.

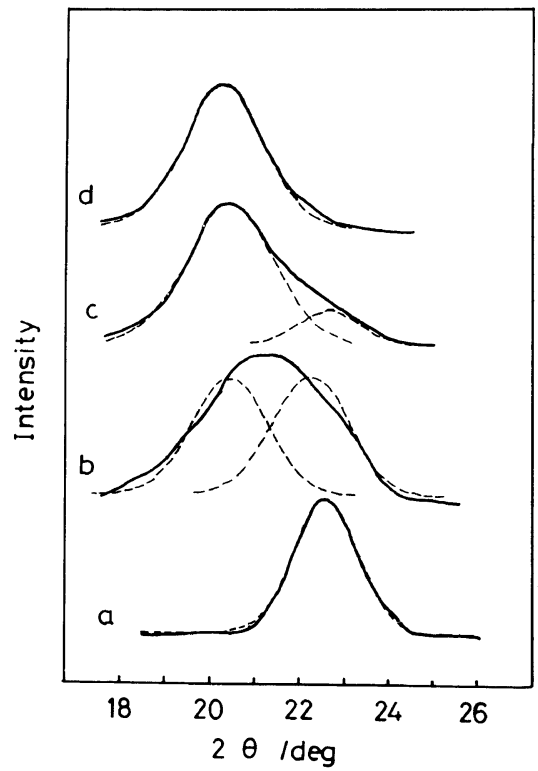

Figure 5. Diffraction intensity ratio of $\mathrm{Na}-\mathrm{Cell} \mathrm{I}$ and complex in $0.005 \mathrm{~S}$ sample: Treatment conditions: $20.0^{\circ} \mathrm{C}$, $24 \mathrm{~h}, \mathrm{NaOH}$ concentration (wt \%); a, 0.2; b, 9.0; c, 10.4; $\mathrm{d}, 18.0$. Dotted lines are $2 \theta$ values of the diffraction peak of Na-Cell $\mathrm{I}$ and the complex (from low angle side), respectively.

shown in Figure 5. The ratio of the diffraction intensity of Na-Cell I to the complex is $1: 1$. On alkali-treatment of more than $10.4 \%$, the production of $\mathrm{Na}$-Cell I becomes remarkable. The diffraction intensity ratio of $\mathrm{Na}-\mathrm{Cell} \mathrm{I}$ and the complex is $4: 1$ for the sample treated with the $10.4 \%$ alkaline solution. The ratio of Cell II and Cell I in this sample is 81:19 after regeneration to cellulose, corresponding well to that of Na-Cell I and the complex. It is suggested that, in the case of $10.4 \%$ alkalitreatment of 0.005 sample, Cell II is formed via the same mercerization process (from $\mathrm{Na}-\mathrm{Cell} \mathrm{I}$ to Cell II) as for the conventional native cellulose. The diffraction diagram of the $18.0 \%$ alkali-swelling 0.005 sample is typical diffraction of $\mathrm{Na}-\mathrm{Cell} \mathrm{I}$ with the peak at $2 \theta=20.0 \pm 0.2^{\circ}$.

Even a 0.005 sample treated with the aqueous solution of low $\mathrm{NaOH}$ concentration forms Cell II. When this sample is treated with $5.0 \%$ 


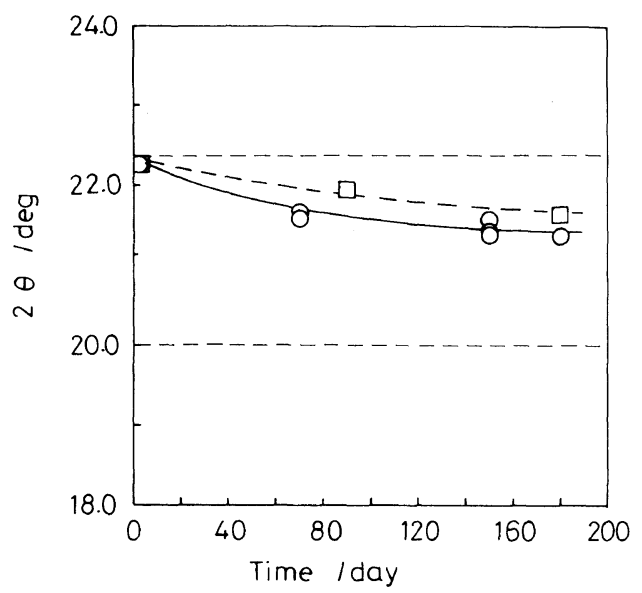

Figure 6. Change in $2 \theta$ value of the diffraction peak of $0.005 \mathrm{~S}$ sample with treatment time (day): $\mathrm{NaOH}$ concentration (wt \%): - $\mathrm{O}-, 5.0$; --- $\square---, 4.3$; temp, $20.0^{\circ} \mathrm{C}$. Upper dotted line, $2 \theta$ value $\left(22.3 \pm 0.2^{\circ}\right)$ of the diffraction peak of the complex; down dotted line, $2 \theta$ value $\left(20.2 \pm 0.2^{\circ}\right)$ of the diffraction peak of $\mathrm{Na}$-Cell I.

or $4.3 \%$ alkali solution for 180 days, Cell II of $90 \%$ or $56 \%$ is yielded, respectively. ${ }^{6}$ However, the X-ray diffraction profiles of these samples show the diffraction peaks at $2 \theta=21.4^{\circ}$ $\left(5.0 \%\right.$ alkali) and $21.7^{\circ}$ (4.3\% alkali), respectively, as shown in Figure 6.

The diffraction profile of the $0.005 \mathrm{~S}$ sample in the range of $2 \theta=19-25^{\circ}$, as shown in Figure $7 \mathrm{a}$, is considered sufficient to indicate the homogeneous structure. Nevertheless, on the assumption that this profile is composed of two profiles due to the complex and alkali cellulose, curve fitting was tried, as shown in Figure $7 \mathrm{~b}$. As a result, the profile can be divided into the profile of the complex with a peak at $2 \theta=22.2^{\circ}$ and the other having a peak at $2 \theta=21.0^{\circ}$. Since the $2 \theta$ value of the diffraction peak of $\mathrm{Na}-\mathrm{Cell} \mathrm{I}$ is $20.0 \pm 0.2^{\circ}$, it is unreasonable that the profile at $2 \theta=21.0^{\circ}$ is regarded as that of Na-Cell $\mathrm{I}$. It is yet unknown which component profile and two components profile shown in Figures $7 \mathrm{a}$ and $7 \mathrm{~b}$ by dotted lines reflects the true structure of $0.005 \mathrm{~S}$ sample. It is, however, certain that the 0.005 sample treated with $5.0 \%$ or $4.3 \%$ alkali does not form Na-Cell I, but does form Cell II by

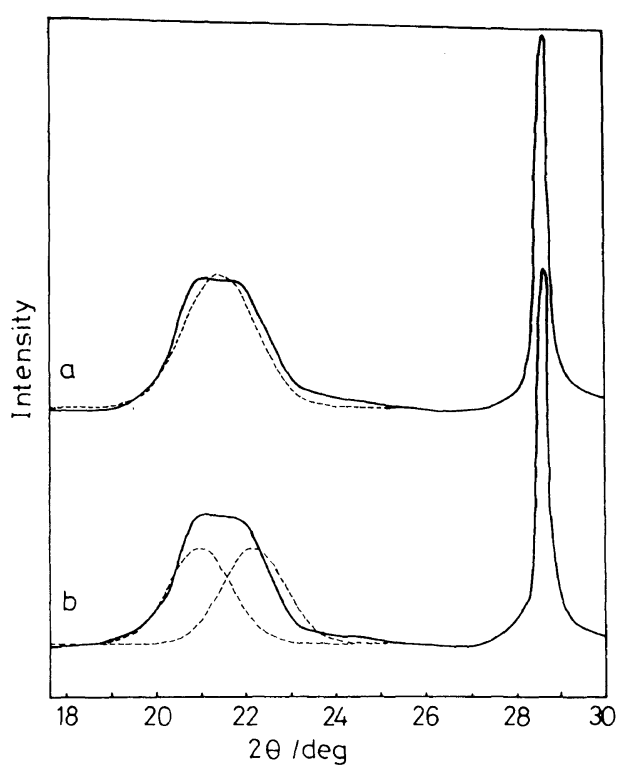

Figure 7. Analysis of diffraction profiles of $0.005 \mathrm{~S}$ sample. Treatment condition: $20.0^{\circ} \mathrm{C}, 180$ days, $5.0 \mathrm{wt} \%$ alkali; a, dotted line indicatcs the fitting curve on the assumuption that the sample is composed of one component (alkali cellulose); b, the dotted line profiles of the alkali cellulose and the complex (from low angle side) on the assumption that the ample is composed of two components (complex and alkali cellulose).

regeneration.

It is suggested that, in the case of the alkali-treatment of the brightener complex with the aqueous solution of low $\mathrm{NaOH}$ concentration, the formation of Na-Cell I and the diffusion of the cellulose chains during the alkali-swelling process are very difficult possibly due to cross-linking of the brightener with the cellulose sheets corresponding to the (110) plane. Indeed, in the case of alkali-treatment of less than $13 \%$, the morphology of the complex changes hardly. ${ }^{4}$ Accordingly, it is very probable that the formation of Cell II occurs only by change in the conformation of the cellulose chains without change of the appearance of the microfibril. Therefore, the orientation of the chains in Cell II obtained from the alkali-treatment of the complex must be equal to that in the conventional bacterial cellulose. 
When nascent bacterial cellulose is soaked in aqueous acetone of more than $60 \mathrm{vol} \%$ at room temperature, it does not change in morphology, but is easily transformed into Cell II. ${ }^{13}$ This fact supports the conclusion described above. From these results, as Hayashi et al. also indicated, ${ }^{14}$ it is strongly suggested that the chain directions of Cells I and II are identical.

\section{REFERENCES}

1. A. Kai, Makromol. Chem. Rapid Commun., 5, 307, 653 (1984).

2. A. Kai and T. Koseki, Polym. Prepr. Jpn., 33, 406 (1984).

3. A. Kai, Polym. Prepr. Jpn., 35, 3676 (1986).

4. A. Kai, P. Xu, and T. Koseki, "Cellulose-Structural and Functional Aspects-," J. F. Kennedy, G. O. Phillips, P. A. Williams, Eds., Ellis Horwood Ltd., Chichester, 1989, p 159.

5. P. Xu and A. Kai, "Cellulose-Structure and
Functional Aspects-, J J. F. Kennedy, G. O. Phillips, P. A. Williams, Eds., Ellis Horwood Ltd., Chichester, 1989, p 165.

6. A. Kai and P. Xu, Polym. J., 22, 655 (1990).

7. A. Sarko and R. Muggli, Macromolecules, 7, 486 (1974).

8. K. Gardner and J. Blackwell, Biopolymers, 13, 1975 (1974).

9. F. Kolpak and J. Blackwell, Macromolecules, 9, 273 (1976).

10. T. Okano and A. Sarko, J. Appl. Polym. Sci., 29, 4175 (1984).

11. T. Okano and A. Sarko, J. Appl. Polym. Sci., 30, 325 (1985).

12. H. Nishimura and A. Sarko, J. Appl. Polym. Sci., 33, 855 (1987).

13. A. Kai, J. Kogusuri, T. Koseki, and H. Kitamura, Cellulose and Wood Chemistry and Technology, C. Sharch, Ed., John Wiley \& Sons Ltd., New York, 1989, p 507.

14. J. Hayashi, H. Kon, M. Takai, M. Hatano, and T. Nozawa, American Chemical Society Symposium. Series, No. 340, The American Chemical Society, Washington D. C., 1987, p 135. 